process, relations between people, and the formation of civic competences; equality as the main principle of functioning, as the principle of equality between participants of the educational process; leading characteristics - freedom, voluntariness, openness and personality-oriented learning; association with popular movements, associations, informal organizations; freedom to participate in educational groups, study at Folk higher schools, educational associations, adult education centers, use of public libraries; Folkeoplysning has great potential for the development of democratic citizenship, as it is able to contribute to solving problems of the local community, and through it to influence democratic shifts in society.

Key words adult education, non-formal adult education, formation of competences, democratic citizenship, N.F. S. Grundtvig, folkeoplysning, folk higher school, study circle, Scandinavian countries.

Удк 378.14:316.723

Олена Слободянюк

Інститут вищої освіти НАПН України ORCID ID 0000-0002-1927-3362

DOI 10.24139/2312-5993/2019.08/023-033

\title{
ДО ПИТАННЯ АКАДЕМІЧНОЇ ДОБРОЧЕСНОСТІ У ВИЩІЙ ОСВІТІ: ПОГЛЯД ЕКСПЕРТІВ США ТА УКРАЇНИ
}

У процесі модернізації вітчизняної вищої освіти особливої уваги заслуговує процес імплементації фундаментальних принципів академічної доброчесності. Метою статmі $\epsilon$ аналіз позитивного досвіду щодо забезпечення академічної доброчесності у вищій освіті США для можливої його реалізації в університетське середовище України. Для досягнення поставленої мети було використано методи порівняння, систематизації наукових та інтернет-джерел. Застосування методу узагальнення дало змогу зробити висновки про отримані результати дослідження: американська вища освіта має глибоку історію академічної доброчесності, тому винятково корисним $\epsilon$ дослідження механізмів запобігання шахрайства й дотримання принципів академічної доброчесності.

Ключові слова: вища освіти, академічна доброчесність, Кодекс доброчесності, плагіат.

Постановка проблеми. Розуміння важливості вітчизняної освітньої спільноти взяти на себе відповідальність за захист норм права і базових академічних та етичних цінностей, забезпечення якості й належних результатів навчання - відображено в низці документів національного рівня, таких як: Етичний кодекс ученого України (2009), у якому основним завданням зазначено надання пріоритету моральним вимірам науки та соціальної відповідальності спільноти вчених і кожного вченого зокрема; зафіксоване поняття «науковий результат» у Законі України «Про наукову та науково-технічну діяльність» (2016), розширений глосарій понять із академічної доброчесності в Законі України «Про освіту» (2016), оприлюднені зобов'язання ЗВО вживати заходів щодо запобігання та виявлення 
академічного плагіату в наукових роботах науково-педагогічних працівників і здобувачів вищої освіти та притягнення їх до дисциплінарної відповідальності в Законі України «Про вищу освіту».

Визначення власних моральних стандартів, їх постійне співставлення з кращими взірцями глобальної академічної культури $є$ необхідними умовами в процесі приєднання України до Болонського процесу та входження до Європейського простору вищої освіти і Європейського дослідницького простору.

Прикладом послідовних системних напрацювань із забезпечення якісних освітніх послуг, які базуються на фундаментальних цінностях, $\epsilon$ досвід університетів та коледжів США.

Аналіз актуальних досліджень. Проблематика академічної доброчесності стала предметом численних публікацій. Зокрема, В. Ромакін проаналізував практики університетів США щодо формування інтелектуальної культури (Ромакін, 2002), дослідив відмінності в мотиваціях, переконаннях і поведінці, пов'язаних із порушеннями норм академічної культури американськими та українськими студентами (Ромакін, 2010); про участь та набутий досвід у програмі «Academic integrity in the U.S.», яку організувало у 2015 р. посольство Сполучених Штатів Америки в Україні поділився В. Хмарський (Хмарський, 2016). Особливу увагу автором приділено висвітленню особливостей фіксації порушення академічної чесності, процедурам та формам документів (Charge of Academic Dishonesty Form), які подаються до Відділу та Рад академічної чесності. Принципи дотримання норм академічної доброчесності і шляхи уникнення неправомірної маніпуляції з дослідницькими даними в управлінні даними дослідження (УдД) на прикладі досвіду світових університетів (у тому числі і у вищій освіті США) та організацій у здійсненні якісного УДД у полі наукової уваги С. Чуканової (Чуканова, 2018), А. Цокур (Цокур, 2009). Т. Ярошенко у книзі «Академічна нечесність та політична культура: порівняльний досвід (Україна - США)» (Ярошенко, 2005) розглядає академічну нечесність у контексті ії взаємозв'язку з політичною культурою. Дослідницею висловлюється думка, що «культурні чинники академічної нечесності в українських вузах ... закорінені в успадкованій від СРСР психології хибно потрактованого колективізму. Його відгуки ми знаходимо в гаслі «один за всіх, і всі - за одного», що розуміється як «кругова порука».

Серед зарубіжних публікацій, присвячених упровадженню принципів академічної доброчесності в освітній процес, варті уваги ідеї T. Gallant (2017), M. DiVall, L. Schlesselman (2016), P. Busch, A. Bilgin (2014).

Тріша Бертрам ґаллант, директор Відділу академічної чесності Каліфорнійського університету в Сан-Дієго та член правління Міжнародного центру академічної чесності, у публікації «Twenty Years of Academic Integrity: Top Articles \& Book Chapters 1992-2012» запропоновано перелік кращих (42 статті/розділи книг) досліджень, присвячених 
проблемам академічної доброчесності, які було опубліковано впродовж двадцяти років (1992-2012рр.). Авторка не тільки оприлюднила рейтинг статей/розділів книг за результатами їх оцінювання рецензентами, а й виклала експертні висновки для кожної публікації.

M. DiVall, L. Schlesselman у статті «Academic Dishonesty: Whose Fault is it Anyway?» проаналізували причини, через які студенти вдаються до недоброчесних практик та запропонували шляхи розв'язання цієї проблеми. Серед причин автори називають: бажання випередити інших, страх невдачі, слабкі навички управління часом, нерозуміння неприпустимості плагіату тощо. Для подолання академічної недоброчесності у студентів пропонується суворе дотримання процедур розслідування та покарання. Роль викладачів дослідники вбачають, у першу чергу, у роз'ясненні студентам наслідків обману в навчанні.

P. Busch та A. Bilgin у статті «Student and Staff Understanding and Reaction: Academic Integrity in an Australian University» аналізують результати загальнонаціонального дослідження щодо ставлення студентів та викладачів австралійських університетів до академічної доброчесності. Існує розрив у розумінні сутності поняття академічної доброчесності та реакцією на нечесну поведінку - головний висновок авторів публікації.

Узагальнюючи низку сучасних публікацій науковців та практиків, пропонуємо в даному дослідженні звернутися до думки американських експертів щодо академічної доброчесності в навчанні, викладанні, дослідженнях, оскільки вища освіта США знаходиться на передових позиціях світової системи освіти.

Метою статті $€$ виявлення позитивного досвіду щодо забезпечення академічної доброчесності в університетському середовищі Сполучених Штатів Америки та можливості його імплементації в систему вищої освіти України. Для досягнення поставленої мети було використано методи порівняння, систематизації наукових та інтернет-джерел, що дало змогу виявити особливості культивування фундаментальних цінностей в університетах держави - світового лідера в освіті. Застосування методу узагальнення дало змогу зробити висновки про отримані результати дослідження.

Виклад основного матеріалу. Американська вища освіта має давні традиції послідовної реалізації принципів академічної доброчесності та довгу історію їі дослідження. Ще в 1964 році Вільям Бауерс (Bowers, 1964) опублікував результати першого широкомасштабного дослідження академічної нечесності в закладах вищої освіти. Він опитав більше 5000 студентів у 99 коледжах і університетах США. За результатами дослідження було з'ясовано, що понад половина всіх респондентів один або більше разів вдавалися до порушень здорових академічних практик. Проблема порушень академічної культури студентами у Сполучених Штатах набула характеру «епідемії» (Haines et al., 1986). 3 метою координації дій із 
формуванням у студентів типу мислення, що надає пріоритет моральному виміру, у США створені спеціальні науково-дослідні інституції, найбільш відомою серед яких є Центр академічної доброчесності (далі - Центр) (Center of Academic Integrity) (з 2010 р. - Міжнародний) (Фундаментальні цінності академічної доброчесності, Center for Academic Integrity Research (2006). Центр академічної доброчесності $€$ консорціумом, до якого входять двісті коледжів та університетів Сполучених Штатів, Канади та Мексики. Центр був заснований у 1992 році та вперше представлений читачам вісника Американської асоціації з питань вищої освіти в листопаді 1995 року в статті «Студентське співробітництво: Не завжди те, чого бажає викладач». Сьогодні головний офіс Центру переміщений до Університету Дюка, де працює в партнерстві з Інститутом Кенана з етики. Зараз Центр налічує 1200 членів у 250 інституціях із 19 країн світу на 6 континентах.

Місією Центру $€$ забезпечувати майданчик для визначення, утвердження та поширення цінностей академічної доброчесності серед студентства. Ця місія досягається головним чином через залучення студентів, викладачів та адміністративних працівників установ-членів, які поширюють серед своїх колегам і спільнот колективний досвід, фахові знання та креативну енергію Центру. Основним інструментарієм, який використовує інституція, $€$ проведення щорічних міжнародних конференцій, організація дослідницьких проектів, розробка керівництв та рекомендацій для аналізу, оцінювання та побудови ефективних стратегій запровадження академічної доброчесності в освітню практику. «... ми можемо запевнити академічну спільноту, - наголошує у вступі до другого видання «Фундаментальних цінностей» Т. А. Фішман (Fishman, 2006), Директорка Міжнародного центру академічної доброчесності, - у своїй рішучості дотримуватися фундаментальних цінностей і їй сприяти, та заохочуємо до підтримки високих стандартів академічної доброчесності на особистому, інституційному та культурному рівнях...».

Ідея створення Центру належить Дональду Маккейбу (McCabe, 1996, р. 28-33). Він є і президентом-засновником, і головою комітету з питань членства Центру академічної доброчесності, професором з менеджменту та глобального бізнесу в Університеті Ратгерса. Професор присвятив увагу ґрунтовному вивченню традиційних та модифікованих Кодексів академічної честі. Дональд Маккейб і Лінда Тревіно (McCabe \& Trevino, 1996, p. 28-33) в статті видання «Change» під назвою «Що ми знаємо про списування в коледжах: Тенденції, досліджені в часі та нещодавня динаміка» зробили висновок, що «клімат або культура академічної доброчесності, виявлена в університеті, може бути найважливішим детермінантом рівня нечесної поведінки студентів у цьому університеті». Автори звертають увагу на типологію Кодексів, традиційних та модифікованих. Так, традиційні Кодекси академічної честі зазвичай 
включають вимоги: іспити, що проводяться без спеціального нагляду, письмові розписки, які студентів просять підписати на засвідчення того, що їхня робота виконана доброчесно, а також роль студентів у системі вирішення справ, що розглядає звинувачення в академічній нечесності. Модифіковані Кодекси честі зазвичай фіксують значну роль студентів у процесі вирішення справ, але не вимагають проведення іспитів без участі наглядачів або використання письмових розписок, хоча це часто може використовуватися на розсуд викладачів з окремих дисциплін.

Дослідження Маккейба і Тревіно, а також робота Білла Боуерса (Bowers, 1964), надає важливе емпіричне підтвердження ефективності таких кодексів. Наприклад, у дослідженні 1995 року, що охоплювало понад 4 тисячі студентів у 31 університеті, Маккейб і Тревіно повідомили про те, що 54 \% студентів в університетах, де запроваджено кодекс честі, визнали один чи більше випадків серйозної нечесної поведінки порівняно з 71 \% студентів в університетах, де немає такого кодексу. Вплив кодексів був навіть ще більш очевидним у кількості студентів, які визнали неодноразові випадки серйозної нечесної поведінки під час тестів/іспитів: 7 \% студентів в університетах, де запроваджено кодекс честі, визнали, що вдавалися до нечесної поведінки, тоді як у закладах без кодексів честі таку поведінку визнали більш ніж вдвічі студентів - 17 \%. І найбільш всеохоплююче дослідження (близько 50000 студентів з більш ніж 60 університетів), проведене Маккейбом виявило, що 70 \% студентів брали участь у тій чи іншій формі порушень норм академічної культури (M cCabe \& Trevino, 1996, р. 28-33). Результатом аналізу ефективності традиційних та модифікованих Кодексів честі став висновок: традиційні кодекси честі $\epsilon$ ефективним інструментом запобігання недоброчесних практик за умови запровадження їх у приватних закладах із малою та середньою кількістю студентів. Натомість у великих університетах складніше розвивати й підтримувати потужне відчуття університетської спільноти, що $є$ важливим фундаментом, на якому може будуватися традиція кодексу честі. Тому Маккейб і Тревіно рекомендують модифікований Кодекс честі, оскільки його вимоги передбачають: обов'язкове значне залучення студентства в систему розгляду справ, спільну роботу з викладачами над зменшенням нечесної поведінки студентів, членство в колегіях із розгляду справ, а також проведення презентацій для інших студентів стосовно важливості доброчесності.

На шляху до досягнення мети (формування особистої відповідальності за процес і результат освітньої діяльності), одним із викликів науковці вбачають академічний плагіат. На сайті Центру академічної доброчесності оприлюднене таке визначення плагіату: «використання чужої роботи чи ідеї, видаючи їх за власні» (International Center for Academic Integrity). Американський учений М. Роіґ (Miguel Roig) у посібнику з академічної чесності зазначає, що «плагіат традиційно визначається як запозичення слів, образів, ідей тощо в автора та представлення їх як власних. Його часто 
асоціюють із такими фразами, як «викрадення слів», «викрадення ідей», «шахрайство» та «літературна крадіжка» (Роіґ, 2015, р. 3). Професор Сиракузького університету (штат НьюЙорк) Р. Мур-Говард (Rebecca Moore Howard) дає описове визначення плагіату: «Плагіат - це представлення слів або ідей джерела як своїх власних. Плагіат відбувається, коли автор не поставив лапок для точних цитат; не послався на джерела своїх ідей; або запозичив звороти з джерел, змінивши граматику або вибір слів» (Moore Howard, 1995, р. 799) - і виділяє три форми плагіату: 1. «Шахрайство запозичення, купівля або отримання іншим чином роботи, написаної кимось іншим, і представлення ії під своїм іменем» (Moore Howard, 1995, р. 799). 2. «Відсутність посилання - це написання власної роботи з внесенням до неї уривків тексту, скопійованих із роботи іншого автора (опублікованої чи ні, із 140 друкованого або електронного джерела) без указування (а) приміток під текстом, кінцевих виносок або посилань у дужках, які цитують джерело і (б) лапок або відступу друкованого блоку (йдеться про спосіб виділення великих за розміром цитат. - О. С.), щоб указати, що саме було скопійовано 3 джерела» (Moore Howard, 1995, р. 799). 3. «Клаптикове письмо» (patchwriting) - написання уривків тексту, що містять парафрази надто близькі до тексту (тобто незначний рерайт); вони є плагіатом, незалежно від того, чи наведено примітки під текстом, кінцеві виноски чи посилання в дужках, які цитують джерело» (Moore Howard, 1995, р. 799). Проте вчена зазначає, що «клаптикове письмо» не завжди є формою академічної нечесності, оскільки до нього можуть вдаватись учні та студенти, які не вміють робити грамотні парафрази через нерозуміння тексту й ідей оригінальної роботи або не знають правил цитування та оформлення посилань.

Таким чином, академічна доброчесність у системі вищої освіти США визначається як критично важлива для забезпечення довіри до наукових результатів та до підтвердження результатів освіти випускників закладів освіти. В Україні увага до проблематики академічної доброчесності виникла через задеклароване бажання долучитись до світових та європейських стандартів та як наслідок публічного викриття численних прикладів академічної недоброчесності (в основному, це були випадки академічного плагіату). Усі учасники освітнього процесу 3 етапу теоретичних розмов про академічну доброчесність мають перейти до етапу відкритої критики порушень, розробити інструменти моніторингу та розгляду виявлених випадків недоброчесності та запровадження концептуальних заходів для попередження академічної недоброчесності. «Основні типи заходів для подолання проблеми академічної недоброчесності в освіті, які пропонуються міжнародними організаціями це коригування поведінки студентів та учнів; покращення викладання; підвищення мотивації до навчання; формування культури академічної доброчесності, у тому числі інституційної культури та культури в 
мікросередовищах (класу, групи)» (Академічна доброчесність. Аналітичний звіт та рекомендації, 2018, с. 19).

Проте, в українській практиці $€$ значний ризик формального імітаційного «запровадження» рекомендацій міжнародних організацій, 3 простим переписуванням перекладених процедур та політик, без детального обговорення чи навіть ознайомлення всіх учасників академічного процесу 3 цими документами (Академічна доброчесність. Аналітичний звіт та рекомендації, 2018, с. 19). У 2009 році за ініціативою Фонду сприяння розвитку демократії Посольства США завдяки об'єднанням громадських організацій було проведено низку просвітницьких заходів, присвячених підтримці та впровадженню Кодексу честі в 3ВО України (Цокур, 2009). У розширеному глосарії термінів та понять ст. 42 «Академічна доброчесність» Закону України «Про освіту» (від 5 вересня 2017 р.), в розділі 4. Етичний кодекс та етична комісія, надається роз'яснення, що «етичний кодекс академічної установи (кодекс академічної етики, кодекс академічної поведінки, кодекс честі, кодекс академічних цінностей університету або наукової установи), визначає загальну філософію функціонування університету або наукового інституту, віддзеркалює та захищає сформовані в ньому позитивні культурні традиції, підтримує цінності доброчесності колективу». Окремі українські ЗВО та наукові інститути прийняли кодекси етики ще на початку 2010-х років. Станом на березень-квітень 2017 р. кодекси етики розмістили на власних сайтах 14 з 200 українських 3ВО, які у 2016 р. входили до рейтингу «Топ-200 Україна». Нова хвиля уваги до кодексів академічної поведінки була зумовлена появою восени 2017 р. в українському законодавстві норм про академічну доброчесність й, у зв'язку з цим, рекомендацією $\mathrm{MOH}$ до ЗВО розробити відповідну внутрішню нормативноправову базу, зокрема, й кодекси етики. Уже станом на грудень 2017 року 73 з 200 зВО (з-поміж охоплених рейтингом «Топ-200 Україна») або розмістили кодекс етики на своїх сайтах, або проінформували про його наявність у закладі без розміщення документа в Інтернеті. Ця остання хвиля прийняття кодексів етики продемонструвала щонайменше три проблеми. Перша - чимало українських 3ВО ухвалюють кодекс етики через «указівку згори», а не на тому етапі розвитку власної академічної культури, коли спільнота університету починає відчувати потребу у формалізації власних етичних та культурних норм і традицій. Друга - навряд чи прийняті в такий спосіб кодекси віддзеркалюють справжні погляди на академічну культуру більшості студентів та викладачів. Адже малоймовірно, що у стислі терміни можна забезпечити повноцінну розробку й належне обговорення такого документа із залученням усієї академічної спільноти. Проте, інформування наукової та освітньої громадськості про відповідні ризики містить можливості щодо підвищення мотивації для всіх освітян та науковців брати участь в обговоренні процедур забезпечення дотримання академічних стандартів та 
оцінювання наукових результатів. Третя - багато нових кодексів дослівно запозичили норми про зміст академічної доброчесності, види ії̈ порушення, санкції із статті 42 закону «Про освіту». Цей факт варто порівняти з досвідом університетів США та Західної Європи, у яких кодекси етики регламентують приблизно однакове коло питань, але кожен кодекс це робить у власний, унікальний спосіб; складно знайти два ідентичних кодекси етики західних університетів. Так, особливістю Кодексу честі університету Бригама Янга (США), який був ухвалений ще у 1940 році, є його відповідність настановам Церкви Ісуса Христа Святих останніх днів. Цікавим $€$ досвід модифікації Кодексу честі Принстонського університету (уперше прийнятий у 1893 році). У первинному варіанті документ вимагав лише чесної поведінки студента на іспиті. У 1980 році Кодекс було модифіковано шляхом суттєвого розширення зобов'язань студентів. В останніх змінах (2015 рік) запроваджена вимога проводити іспити без присутності викладача. За порушення Кодексу честі можуть накладатися дисциплінарні стягнення, призупинятися навчання, відраховуватися студенти (Хмарський, 2016, с. 67).

Проблеми необдуманої екстраполяції світового досвіду в український освітній простір породжують ризики неефективності української версії академічних кодексів етики, відсутності їх впливу на поліпшення відносин усередині академічної спільноти, суто формального статусу вказаного документа, а також, навпаки, ризики застосування положень кодексу як способу тиску на членів університетської спільноти (наприклад, будь-якого викладача завжди можна звинуватити в необ'єктивному оцінюванні, оскільки воно структурно передбачене освітньою системою). У великих університетах можна приймати рамковий кодекс етики для закладу в цілому і деталізовані, зокрема, щодо процедурних питань документи на рівні окремих факультетів та інститутів.

Етичні кодекси, як і будь-які інші інструменти забезпечення академічної доброчесності, не можуть гарантувати вирішення всіх проблем, пов'язаних із неетичною поведінкою в освіті. Перш за все, вони покликані звести в один комплекс неписані правила та норми поведінки, щоб покращити обізнаність академічної спільноти та унормувати процедури розгляду різних академічних переступів. Етичні кодекси навряд чи здатні самотужки забезпечити дотримання етичних принципів та вирішити проблему академічної недоброчесності, адже вона походить від кількох глибших криз українського суспільства в цілому та вищої освіти в Україні зокрема.

Висновки та перспективи подальших наукових розвідок. Отже, наведений міжнародний досвід із забезпечення академічної доброчесності, зокрема США, показовий у тому, що світові університети розглядають нечесність як загрозу своєї безпеки і вважають, що згубні звички є причиною розладу в академічній сфері. Такі дії можуть призвести до відрахування студента, звільнення викладача із складу університетської спільноти, а ЗВО 
втратити свій імідж. Тому кожен університет прагне розвивати та модифікувати механізми забезпечення академічної доброчесності.

3 метою уникнення деградації вищої освіти та втрати репутації в публічному просторі саме такі практики повинні стати взірцем для системної діяльності, орієнтованої на перехід до відкритих та прозорих процедур забезпечення дотримання стандартів академічної доброчесності та академічної етики, яке має включати моніторинг та дотримання процедур розгляду конкретних порушень, без приховування таких порушень, а також покарання практики академічної недоброчесності.

\section{ЛІТЕРАТУРА}

Академічна доброчесність. Аналітичний звіт та рекомендації. Режим доступу: https://rpr.org.ua/ wp-content/uploads/2018/10/Analitychna-zapyska-akademichnadobrochesnist.pdf (Academic integrity. Analytical report and recommendations. Retrieved from: https://rpr.org.ua/wp-content/uploads/2018/10/Analitychnazapyska-akademichna-dobrochesnist.pdf

Ромакін, В. В. (2002). Академічна чесність у вищій освіті. Наукові праці чорноморського державного університету імені Петра Могили, 7, 23-28 (Romakin, V. V. (2002). Academic honesty in higher education. Petro Mohyla Black Sea National University Proceedings, 7, 23-28).

Ромакін, В. В. (2010). Мотивації, переконання та поведінка українських і американських студентів бакалаврату щодо норм академічної культури. Наукові праці Чорноморського державного університету імені Петра Могили, 123, 4-41 (Romakin, V. V. (2010). Academic honesty in higher education. Petro Mohyla Black Sea National University Proceedings, 123, 4-41).

Фундаментальні чінності академічної доброчесності. Режим доступу: https://academicintegrity.org/wp-

content/uploads/2019/04/Fundamental Values version in Ukrainian.pdf (The Fundamental Values of Academic Integrity. Retrieved from: https://academicintegrity.org/wpcontent/uploads/2019/04/Fundamental Values version in_Ukrainian.pdf).

Хмарський, В. М. (2016). Academic integrity в США: кілька спостережень 2015. У Т. В. Фініков (ред.), Академічна чесність як основа сталого розвитку університету, сс. 53-92. К.: Таксон (Khmarskyi, V. М. (2016). Academic integrity in the USA: a few observations. In T. V. Finikov (Ed.), Academic integrity as a basis for sustainable development of the university, (pp. 53-92). K.: Tacson).

чуканова, С. (2018). Дотримання норм академічної доброчесності у процесі управління дослідницькими даними: зарубіжна практика. Український журнал 3 бібліотекознавства та інформаційних наук, 2, 52-63 (Chukanova, S. (2018). Academic integrity norms compliance in the process of research data management: foreign practice. Ukrainian Journal on Library and Information Science, 2, 52-63).

Цокур, А. С. (2009). «Кодекс чести» в системе высшего образования США. Вестник Черкасского национального университета имени Богдана Хмельницкого, 150, 57-62 (Zokur, A.S. (2009). «Honor Code» in the US higher education system. Cherkasy National University named after Bogdan Khmelnitsky Bulletin, 150, 57-63).

Ярошенко, Т.О. (2005). Академическая нечестность и политическая культура: сравнительный опыт (Украина - США). А. Гомілко (ред.), Призвание 
университета, (сс. 168-175). К.: PIA «янко», «Веселка» (Yaroshenko, Т. О. (2005). Academic dishonesty and political culture: a comparative experience (Ukraine - USA). University calling. In A. Gomilko (Ed.), University calling, (pp. 168-175). K.: "Yank", "Rainbow").

Bowers, W. J. (1964). Student dishonesty and its control in college. New York: Bureau of Applied Social Research, Columbia University.

Haines, V. J., Diekhoff, G. M., LaBeff, E. E., Clark, R. E. (1986). College Cheating: Immaturity, lack of commitment, and the neutralizing attitude. Research in Higher Education, 25 (4), 342-354.

Center for Academic Integrity Research (2006). Retrieved from: http://www.academicintegrity.org/cai_research.asp. (last accessed on 08/10/2006).

M cCabe, D. L., Trevino, L. K. (1996). «What We Know About Cheating in College: Longitudinal Trends and Recent Developments». Change, Vol. 28, No. 1, 28-33.

McCabe, D. (2005). New CAI Research. Retrieved from:_http://www.academicintegrity.org/ cai_research.asp (last accessed on 07/29/2005).

Moore Howard, R. (1995). Plagiarisms, Authorships, and the Academic Death Penalty. College English, Vol. 57, No. 7, 788-806. Retrieved from: http:// surface.syr.edu/cgi/view content.cgi?article $=1002 \&$ context=wp.

Roig, M. Avoiding plagiarism, self-plagiarism, and other questionable writing practices: $A$ guide to ethical writing. Retrieved from: https:// ori.hhs.gov/images/ddblock/plagiarism.pdf.

Why Integrity? International Center for Academic Integrity. Retrieved from: http://www .academicintegrity.org/icai/ integrity-1.php.

\section{PЕЗЮМЕ}

Слободянюк Елена. К вопросу об академической добросовестности в высшем образовании: взгляд экспертов США и Украины.

В процессе модернизации отечественного образования особого внимания заслуживает процесс имплементации фундаментальных принципов академической добросовестности. Целью статьи является анализ положительного опыта по обеспечению академической добросовестности в высшем образовании США для возможной его реализации в университетскую среду Украины. Для достижения поставленной цели были использованы методы сравнения, систематизации научных и интернет-источников. Применение метода обобщения позволило сделать выводы о полученных результатах исследования: американское высшее образование имеет глубокую историю академической добросовестности, поэтому исключительно полезны исследования механизмов предотвращения мошенничества и соблюдения принципов академической добросовестности.

Ключевые слова: высшее образования, академическая добродетель, Кодекс добродетели, плагиат.

\section{SUMMARY}

Sobodianiuk Olena. On the issue of academic integrity in higher education: a view of experts from the USA and Ukraine.

In the process of modernization of national higher education, the process of implementation of the fundamental principles of academic integrity deserves special attention. The fact that in the process of modernization of national higher education the emphasis on the need to formulate a policy of ensuring academic integrity in the university environment has become one of the key trends, as evidenced by the provisions of the Law of Ukraine "On Higher 
Education" (2014), Law of Ukraine "On Education" (2017), Law of Ukraine "On Scientific and Scientific-Technical Activities" (2016) and other documents. The requirements of academic standards are contained in numerous international instruments, such as, for example, the European Charter for Researchers, which defines the requirements for the activities of researchers. The document contains an Ethical Principles section, which stipulates that scientists must adhere to generally accepted ethical standards and fundamental ethical principles in their disciplines, and to broad requirements for research rules. Therefore, the problem of academic integrity in higher education is urgent. In our view, it is important to highlight the experience of the United States as a leader in the world of higher education systems in maintaining high ethical standards in teaching, teaching and research.

The purpose of the article is to analyze the positive experience of providing academic virtue in US higher education for possible implementation in the university environment of Ukraine. M ethods of comparison, systematization of scientific and Internet sources were used to achieve this goal. The use of generalization method has led to the conclusions of the research findings: American higher education has a deep history of academic integrity, so it is extremely useful to investigate the mechanisms of fraud prevention and adherence to the principles of academic integrity. Extrapolation of world experience to the Ukrainian educational space should be considered in order to avoid the risk of inefficiency of the Ukrainian version of academic codes of ethics, and their influence on the improvement of relations within the academic community. Therefore, international experience in providing academic integrity, in particular United States, is important as world universities view dishonesty as a threat to their security and believe that bad habits are the cause of academic failure.

Key words: higher education, academic integrity, code of academic integrity, plagiarism.

удк 376.1:371.1:37.08:378

Володимир Шевченко

Інститут спеціальної педагогіки і психології

імені Миколи Ярмаченка НАПН України

ORCID ID 0000-0003-0119-3206

DOI 10.24139/2312-5993/2019.08/033-042

\section{РОЗВИТОК ІНКЛЮЗИВНИХ ТА ІНТЕГРАЦІЙНИХ ПРОЦЕСІВ У ПОЛЬЩІ НА СУЧАСНОМУ ЕТАПІ}

У статті автор висвітлює сучасний розвиток інклюзивних та інтеграційних процесів у Польщі. Були використані методи аналізу, пошуку, систематизації та узагальнення. Автор характеризує підходи та умови до організації інклюзивного навчання; окреслює питання психолого-педагогічного супроводу учнів із особливими освітніми потребами, а також концептуальні основи підготовки корекційних педагогів. Автор зазначає, що хоча на сьогодні в Польщі інклюзивне навчання $\epsilon$ основною формою здобуття освіти дітьми з особливими потребами, проте вони можуть здобувати освіту і в спеціальних закладах освіти, які є альтернативними. Подальших розвідок потребує вивчення інклюзивного навчання дітей із особливими потребами на різних освітніх ланках.

Ключові слова: інклюзивна освіта, інклюзивне навчання, інтеграція, спеціальна освіта, діти з особливими освітніми потребами, психолого-педагогічний супровід, підготовка фрахівців, Польща. 